Copyright (C) 2021 by Cherkas Global University

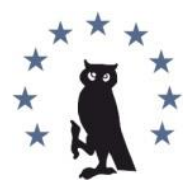

Published in theUSA

Propaganda in the World and Local Conflicts

Has been issued since 2014 .

E-ISSN 2500-3712

2021. 8(2): 81-86

DOI: 10.13187/pwlc.2021.2.81

https://pwlc.cherkasgu.press

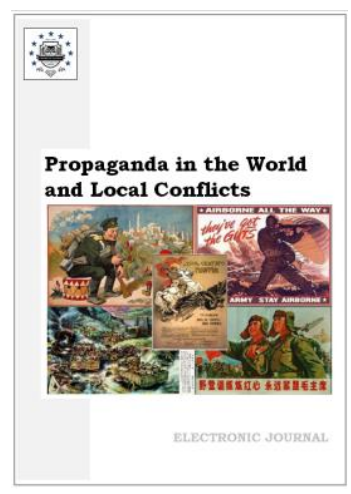

\title{
The Use of High-Powered Loudhailer Units by the Red Army on the Front during World War II
}

\author{
Vadim A. Nesterenko ${ }^{a}$, \\ a Sumy State University, Sumy, Ukraine
}

\begin{abstract}
This work draws upon archival materials and materials of private origin to examine the use of the MGU-39, a high-powered loudhailer unit, by the Red Army during World War II. It describes certain technical means and methods employed by propagandists to conduct agitation, including via the use of misleading sounds.

A key source used was the reminiscences of announcer and translator L.G. Nagler (married name Gerulaitis), who during the war was a member of a team operating a high-powered loudhailer unit while serving in the 11th Army of the Workers' and Peasants' Red Army (RKKA). Use was also made of archival materials, namely reports recording the use of an MGU-39 by the $5^{\text {th }}$ ("to misinform the enemy"), 48th, and 65th Armies of the RKKA. The documents were obtained from the Central Archive of the Ministry of Defense of the Russian Federation (Podolsk, Russian Federation).

The author's conclusion is that the MGU-39, created in 1941, was employed throughout World War II. In a period of defensive action, the unit was employed to subvert enemy troops through agitation. For these purposes, special propaganda materials were designed and use was made of prisoners. Broadcasting of this kind was normally conducted in the nighttime.

At a time of the Soviets advancing, the unit was employed to create noises designed to mislead the enemy (e.g., by means of artificially reproducing or, on the contrary, drowning out the sound of tanks moving). In the areas of operation of the 5th, 48th, and 65th Armies, this kind of work was a great help to the advancing Soviet units. In addition, the MGU-39 was employed at the time to help provide agitation support for the Red Army's own units.

Keywords: sound broadcasting station, high-powered loudhailer unit, MGU-39, reminiscences, propagandists, leaflets.

\section{Introduction}

Relatively little recorded history exists about the use of the MGU-39, a high-powered loudhailer station, on the front. This may be associated with the negligible number of such stations at the time - just 1-2 on an entire front. The station was primarily intended for the conduct of psychological operations aimed at agitating enemy troops into crossing over to the Soviet side. However, the effectiveness of this kind of activity remained low up until 1943, with there being just a few cases of members of the German armed forces crossing over to the Soviet side as a result. Starting in 1943, such stations were employed with the aim of misleading the enemy (e.g., by means of artificially reproducing or, on the contrary, drowning out the sound of tanks moving).
\end{abstract}

\footnotetext{
${ }^{*}$ Corresponding author

E-mail addresses: nva2008@ukr.net (V.A. Nesterenko)
} 
The MGU-39 was added to the military's arsenal in 1941, on the eve of World War II. The unit had a range of 3-4 km, or even more in good weather conditions. The present work examines the use of the MGU-39 by the 5th, 11th, 48th, and 65th Armies of the Workers' and Peasants' Red Army (RKKA).

\section{Materials and methods}

A key source used was the reminiscences of announcer and translator L.G. Nagler (married name Gerulaitis), who during the war was a member of a team operating a high-powered loudhailer unit while serving in the 11th Army of the RKKA (Gerulaitis, 2010). Use was also made of archival materials, namely reports recording the use of an MGU-39 by the $5^{\text {th }}$ "to misinform the enemy") (TsAMO RF. F. 201. Op. 390. D. 15. L. 32-35), 48th, and 65th Armies of the RKKA (TsAMO RF. F. 201. Op. 390. D. 15. L. 58-61). These documents were obtained from the Central Archive of the Ministry of Defense of the Russian Federation (Podolsk, Russian Federation).

Methodologically, use was made of a set of principles fundamental to historical-military research, including those of historicism, systemicity, and objectivity. The simultaneous use of these principles helped examine the use of the MGU-39 on World War II front lines in the context of the historical situation at the time and through the lens of certain adjacent events (e.g., the use of the MGU-39 in periods of defensive and offensive action). Use was made of all the documents found to gain the most comprehensive insight possible into the Red Army's use of the MGU-39 on the Eastern Front.

\section{Results}

The first example that will be examined in this work is the use of the MGU-39 by the 11th Amy's MGU-39 team, headed by Captain Kogan. The use of the MGU-39 was described in the recollections of announcer and translator Liba Grigor'evna Nagler (married name Gerulaitis). L.G.Nagler was born in 1924 in Moscow. In the fall of 1942, she joined the army at the age of 18. She could speak German, so she was sent to work for the 7th Division of the 11th Army's Political Department, concerned with conducting special work amongst enemy troops. L.G. Nagler was appointed to the role of Announcer/Translator within the MGU-39 team. Based on her reminiscences, the MGU-39 was a GAZ-AA truck borne unit (Figure 1) with an extension loudspeaker connected to the truck by a 300-meter cable (Figure 2).

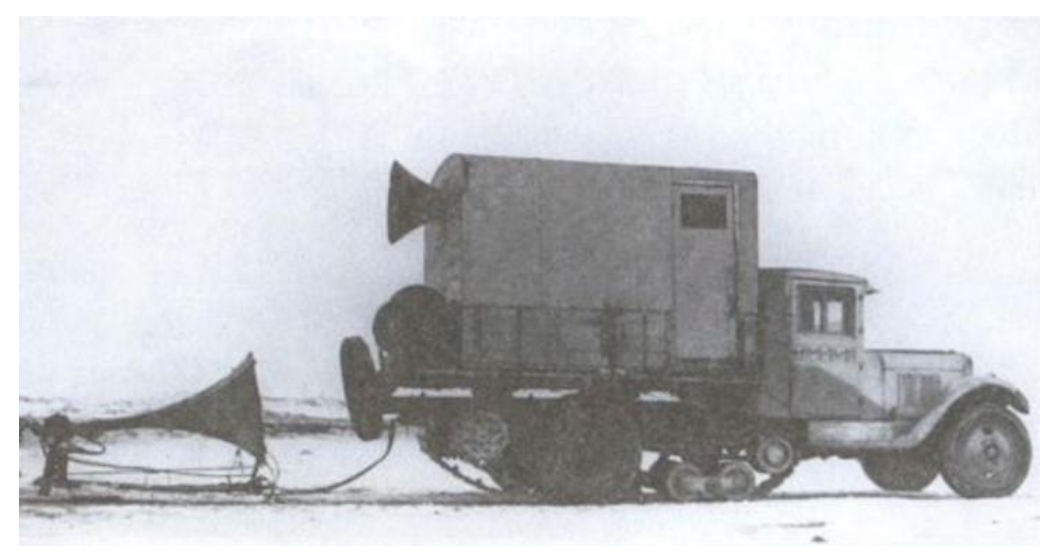

Fig. 1. MGU-39 


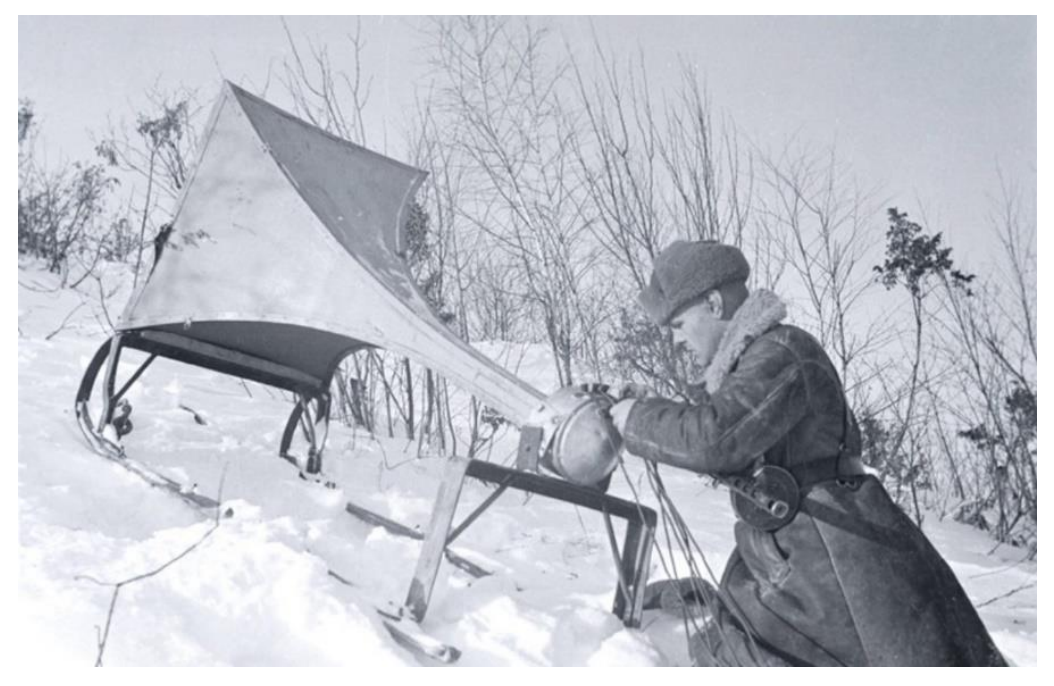

Fig. 2. Loudspeaker being moved to the forward line

If it was not possible for the truck to get to the front line, use would be made of the OZU, a mobile trench loudhailer unit (Figure 3).

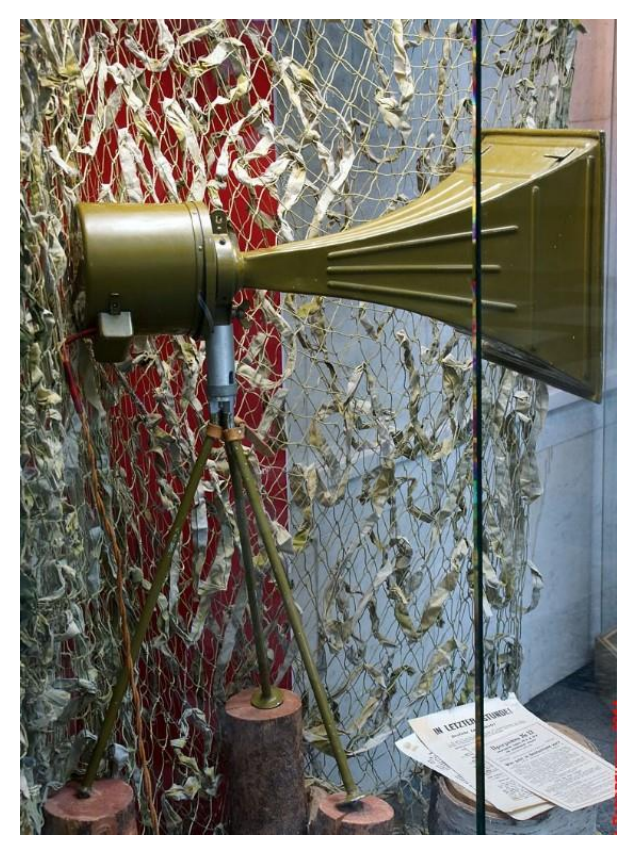

Fig. 3. Trench loudhailer unit (OZU)

A typical MGU-39 team consisted of four regular crewmembers: an operations manager, an announcer/translator, a radio operator/technician, and a driver. The team was guarded by two soldiers (Gerulaitis, 2010: 30).

For agitation purposes, use would be made of broadcasts in German and leaflets. L.G. Nagler would read out news from Soviet Informbureau - above all, news about Soviet troops' victories and advances. The more the German army retreated, especially after the Battle of Stalingrad, the more detailed such news bulletins became. In addition, the announcer would call on the Germans to surrender and tell them about conditions in captivity (e.g., the amounts of bread, butter, meat, tobacco, etc.). Such broadcasts would take place only in the nighttime. Broadcasting was possible at the time only in a climate of positional warfare. It must be admitted that the MGU-39 was something disliked by the Germans and Soviet troops alike, as, given its range of nearly three kilometers, both German and Soviet service members faced sleep deprivation as a consequence of such broadcasts. 
L.G. Nagler would normally start a broadcast with the March from the opera Aida. She would then read out a text, and would conclude the broadcast with Grieg's Solveig's Song. Every time the music would be broadcast, the Germans would respond with heavy fire. The Germans would try to drown out the sound from the MGU-39 with their shooting. There were times when shooting would subside amid German letters (captured by Soviet intelligence) being read out to and captive Germans addressing the German side.

The enemy's mood changed significantly subsequent to the Battle of Stalingrad. By that time, Germany itself had been subjected to massive bombardment, with food shortages ensuing something communicated in letters to those on the front. Propagandists drew up bulletins for the General Staff regarding the situation in the enemy rear based on such letters, and employed them for agitation purposes as well. It must be understood that the reading out of German letters would be possible at the time only when Soviet intelligence had intercepted German military mail (Gerulaitis, 2010: 30).

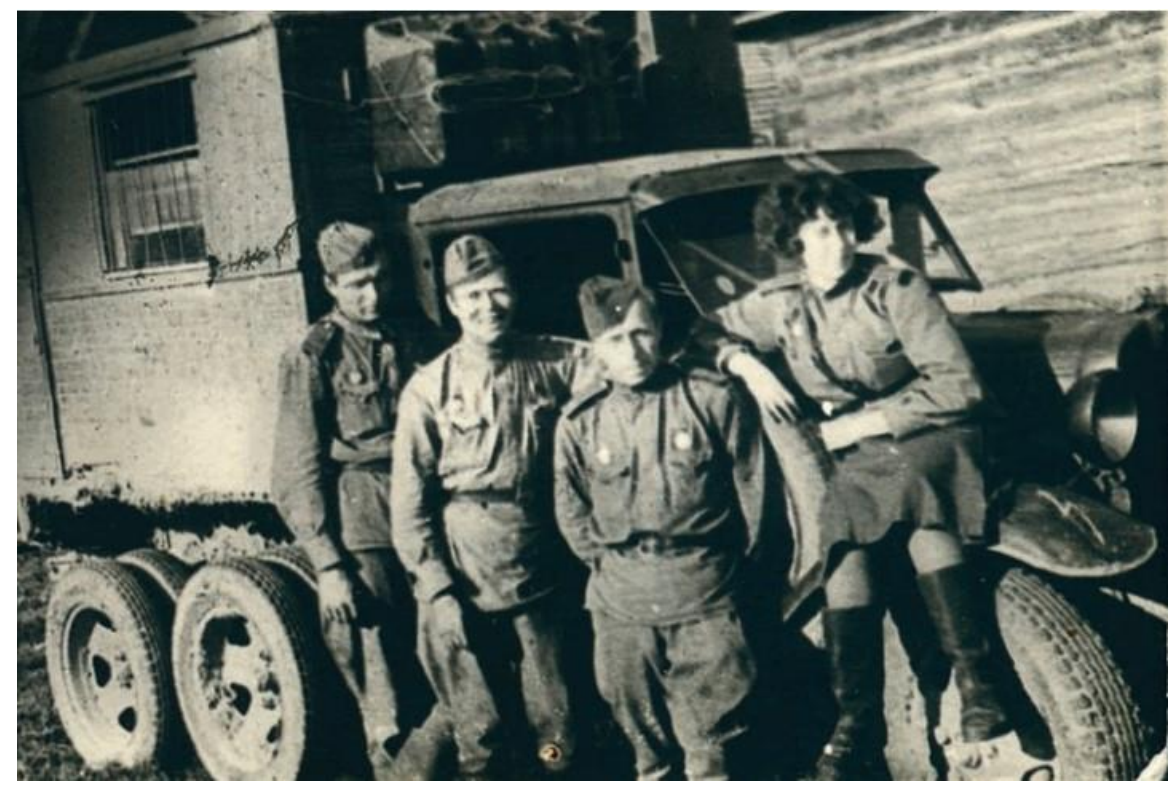

Fig. 4. 11th Army's MGU-39 team: Captain Kogan, Larin (artificer), Sergeant Afanas'ev, and Nagler (announcer/translator). Oryol Oblast. August 1943 (Gerulaitis, 2010: 31)

The team's crew chief was Lev Moiseevich Kogan, who in February 1943 worked as an instructor at the Political Department of the 33th Tank Brigade of the 2nd Mechanized Corps. Captain Kogan was born in 1915 in Kiev. He had been serving in the RKKA since 1937. As at February 1943, he had no battle injuries and no awards. In February 1943, he was decorated with a Medal of Valor. The awards and decorations documentation contains the following information on him: "While working as an agitator at the brigade's Political Department, Comrade Kogan has fought as part of the brigade in the front line during its battle action. He has done a great job of organizing educational work with the personnel and mobilizing them for the fulfillment of the battlefield mission. He has been brave and assertive. During the advance on Bryukhin and Botovo, he participated in charging the enemy's line" (TsAMO RF. F. 33. Op. 682525. D. 425. L. 63). It turns out that Captain Kogan was not a member of the MGU-39 team prior to 1943. He must have joined the team subsequent to the Battle of Stalingrad. The awards and decorations documentation contains no information about the other members of the crew.

As regards prisoners, according to L.G. Gerulaitis, "the prisoners would say in broadcasts that they were not hurt, were fed, were given cigarettes and soap, and, in general, were treated in compliance with the international regulations of the Red Cross movement" (Gerulaitis, 2010: 31). Sometimes this kind of agitation did help get enemy service members to defect. These mostly were Czechs and Austrians, although there were Germans too. It is to be noted that the requirement that captive enemy troops be employed more often as part of agitation broadcasts was established back on February 26, 1942, by the Main Political Administration of the Red Army via the directive 
'On the Objectives for Propaganda amongst Enemy Troops' (TsAMO RF. F. 208. Op. 2511. D. 2298. L. 57-57ob.).

The MGU-39 team participated in putting together leaflets. The leaflets normally contained quotes from the speeches of Joseph Stalin, like the following one from a speech he delivered in 1942: "Hitlers come and go, but the German people remain". Propagandists were to translate this kind of quotes and include them in leaflets (Gerulaitis, 2010: 31).

There were several ways of getting the leaflets to the front line. They were mainly dropped from airplanes, with artillery (propaganda ammunition) and intelligence (during raids to the enemy line) employed as well (TsAMO. F. 1345. Op. 1. D. 116. L. 147).

There is a method for distributing leaflets that was developed by the MGU-39 team L.G. Nagler was a member of. Here is how she personally describes it: "Our chemical warfare unit had provided us with what we call "ampoule throwers", initially designed to pelt the enemy with easy-to-break ampoules containing chemical agents. However, considering that there was no chemical warfare going on at that time, it was decided to make a different use of such ampoules charge them with leaflets. Launched with an ampoule thrower, the ampoules would fly for about 100 meters and land just short of the German trenches. On landing, the ampoules would break, with the leaflets getting scattered all over the ground (Gerulaitis, 2010: 31).

The MGU-39 was used by other armies as well.

In 1943, subsequent to the Red Army's shift from defense to offense, the MGU-39 began to be used for creating misleading noise as well. For instance, it was employed by the 6th Army during the Soviet advance in the vicinity of the town of Sevsk. Prior to storming Sevsk, the Army Command directed the MGU-39 team to create misleading noise to drown out the sound of the approaching tanks. As a result, on August 26, 1943, the MGU-39 team spent the entire night drowning out the sound of the approaching tanks and artillery with music and text (TsAMO RF. F. 201. Op. 390. D. 15. L. 32). In the morning, the Soviet troops stormed the town and captured it. By contrast, on September 8, 1943, the team engaged in artificially reproducing the sound of tanks moving to mislead the enemy into thinking there were tanks approaching the enemy strongpoint (TsAMO RF. F. 201. Op. 390. D. 15. L. 32). On October 1, the MGU-39 was set up near a crossing with the aim of drowning out the sound of the tanks crossing the River Sozh (TsAMO RF. F. 201. Op. 390. D. 15. L. 32). This was done in such a lifelike manner that the Germans even dispatched a reconnaissance aircraft on a moonlight night to have that information confirmed (TsAMO RF. F. 201. Op. 390. D. 15. L. 59ob.). Similar work was carried out by the 48th Army as well.

Particularly extensive work in terms of artificial reproduction of the sound of tanks approaching or battling was carried out by the MGU-39 team of the 19th Rifle Corps of the 65th Army October 4 through 6, 1943. Here, the MGU-39 team had the task to drown out the sound of the Soviet tanks crossing to the right bank of the River Sozh in the vicinity of the village of Novyye Tereshkovichi. The MGU-39 team conducted broadcasting from the bank of the River Sozh from 2:30 am to 5:30 am. Half of the tanks crossed without sustaining any losses. The enemy, who earlier had been shooting up the crossing, began to shoot up the MGU-39 area during the broadcast, with the tanks taking advantage of the shift of fire to complete the crossing (TsAMO RF. F. 201. Op. 390. D. 15. L. 60). In the morning of October 5, it was resolved that the 19th Rifle Corps would undertake an advance. Prior to the Soviets' artillery softening up in the vicinity of the village of Fedorovka, the MGU-39 team conducted from the edge of the forest a broadcast reproducing the sound of tanks moving into the area (four sessions, each an hour long). As early as 15 minutes in, the enemy, positioned to the right of the road to Fedorovka, opened powerful artillery fire on the road leading to Fedorovka. Thirty minutes later, the enemy, positioned along the River Sozh west of Fedorovka, opened fire with six-barreled mortars on the approaches to Fedorovka. However, that was firing on empty areas. After the MGU-39 team finished work and left the place, the enemy unleashed fierce artillery fire on the spot where the MGU-39 had been working (TsAMO RF. F. 201. Op. 390. D. 15. L. 60-60ob.). While the enemy were waiting for the tanks to appear in the vicinity of the Fedorovka and concentrated their artillery fire on this sector, the Soviet tanks, subsequent to the artillery softening up, successfully attacked the enemy in the vicinity of the village of Novyye Tereshkovichi, where the tanks had not been expected to appear (TsAMO RF. F. 201. Op. 390. D. 15. L. 6oob.). On October 5, 1943, at 10:30 am the MGU-39 was directed to conduct a broadcast reproducing the sound of tanks moving into the area against a well-fortified enemy stronghold in the village of Novyye Dyatlovichi. At 12:30 am, the MGU-39 team began to broadcast the sound of 
tanks moving for the conduct of an offensive in the forest against the Novyye Dyatlovichi stronghold. On hearing the sound of a large number of tanks moving in, the enemy left their positions. That made it easier for the Soviet infantry to accomplish the task (TsAMO RF. F. 201. Op. 390. D. 15. L. 60ob.).

In the period from November 1 to November 10, the use of the MGU-39 was a great help to the Command of the 3rd Army in carrying out a number of operations. Specifically, on November 2, the Chief of the Army Staff in association with representatives of all arms of the armed forces developed a plan for misleading the enemy using the MGU-39. Upon approval of the plan by the army's Military Council on November 6, they set about carrying the task into effect. A broadcast reproducing the sound of tanks moving was conducted in the sector of the 121st Guards Rifle Division in the vicinity of the villages Strumen and Korsun. During the broadcast, the enemy opened artillery fire on the MGU-39 team three times, which indicates that they were successfully misled into believing in Soviet tanks gathering at the edge of the forest by the village of Strumen. The MGU-39 was used in the early hours of November 7, in the morning of November 7, and in the early hours of November 8 (TsAMO RF. F. 201. Op. 390. D. 15. L. 60ob.-61). The RKKA's experience of employing the MGU-39 to mislead the enemy indicates that the use of artificially reproduced sounds was a great help to many of its units in carrying out combat operations.

Overall, based on the information available today, the two MGU-39 teams of the RKKA's $5^{\text {th }}$ Army conducted in June 1944 a combined 503 broadcasts, with 207 of those being based on materials from the National Committee for a Free Germany, 50 being related to the Allied landings in northern France, and 10 being short addresses by defectors. The units also had six trench sound broadcasting stations, which were used to conduct a combined 622 broadcasts around the same time (TsAMO RF. F. 460. Op. 5047. D. 544. L. 74).

Following the start of the Soviet advance, broadcasting would be conducted in respect of the Soviets' own troops as well. This included the broadcasting of orders from the Supreme Commander, messages from the military councils of the army and the front, and recorded music (TsAMO RF. F. 460. Op. 5047. D. 544. L. 74).

As the hostilities drew to a close, the number of loudhailer units in the Red Army increased, with even division level units getting an MGU-39 team of their own (TsAMO. F. 33. Op. 690155. D. 7515. L. 144).

\section{Conclusion}

The MGU-39, created in 1941, was employed throughout World War II. In a period of defensive action, the unit was employed to subvert enemy troops through agitation. For these purposes, special propaganda materials were designed and use was made of prisoners. Broadcasting of this kind was normally conducted in the nighttime.

At a time of the Soviets advancing, the unit was employed to create noises designed to mislead the enemy (e.g., by means of artificially reproducing or, on the contrary, drowning out the sound of tanks moving). In the areas of operation of the 5th, 48th, and 65th Armies, this kind of work was a great help to the advancing Soviet units. In addition, the MGU-39 was employed at the time to help provide agitation support for the Red Army's own units.

\section{References}

Gerulaitis, 2010 - Gerulaitis, L.G. (2010). Obezoruzhivayushchii golos [Disarming Voice]. Ogonek. 16 (5125):30-32. [in Russian]

TsAMO RF - Tsentral'nyi arkhiv ministerstva oborony Rossiiskoi Federatsii [Central archive of the Ministry of Defense of the Russian Federation]. 